Brit. J. vener. Dis. (1958), 34, 192.

\title{
DIAGNOSIS OF TRICHOMONAS VAGINALIS URETHRITIS IN THE MALE AS A ROUTINE CLINIC PROCEDURE*†
}

\author{
BY
}

C. S. NICOL

Lydia Department, St. Thomas's Hospital, London

Between April 23, 1956, and April 22, 1957, 583 male patients were diagnosed as having nongonococcal urethritis at the Venereal Diseases Department at St. Thomas's Hospital, London. 466 of these patients were whites while the other 117 were Negroes. A search for the Trichomonas vaginalis in the genital tract was made in every case by the direct moist-slide method. The material examined was obtained from one or more of the following sources:

(1) urethral discharge;

(2) urethral scrape;

(3) centrifuged urine.

\section{Material}

Cultures of the urethral discharge or scrape were taken from 245 patients, using the FeinbergWhittington medium (Feinberg and Whittington, 1957). These cultures were examined once after $48 \mathrm{hrs}$ ' incubation in the great majority of cases; in a few cases a second examination was made after $96 \mathrm{hrs}$ ' incubation. All these tests were performed and read by the clinic staff.

\section{Results}

There were 42 positive findings which resulted in the diagnosis of Trichomonas vaginalis urethritis in 29 patients (Table I).

TABLE I

RESULTS IN 583 PATIENTS WITH NON-GONOCOCCAL URETHRITIS

\begin{tabular}{|c|c|c|c|c|c|}
\hline \multicolumn{3}{|c|}{ Material } & Total Cases & $T$. vaginalis & $\begin{array}{l}\text { Per cent. } \\
\text { Positive }\end{array}$ \\
\hline \multicolumn{2}{|c|}{ Urethral Smear } & . & 266 & 1 & 0.4 \\
\hline \multicolumn{2}{|c|}{ Centrifuged Urine } & . & 188 & 7 & $3 \cdot 7$ \\
\hline \multicolumn{2}{|c|}{ Urethral Scrape } & . & 205 & 13 & $6 \cdot 3$ \\
\hline Cultures & $\begin{array}{l}\text { Smear } \\
\text { Scrape } 2\end{array}$ & $\begin{array}{r}40 \\
205\end{array}$ & 245 & 21 & $8 \cdot 6$ \\
\hline
\end{tabular}

* Received for publication March 12, 1958.

+ Part of a paper presented at the XI International Congress of Dermatology at Stockholm in August, 1957.
The direct slide results were positive in seventeen of 29 patients, and the cultures were positive in 21 of 26 patients (Table II).

TABLE II

METHOD OF DIAGNOSIS

\begin{tabular}{c|c|c}
\hline Slide & Culture & No. of Cases \\
\hline Positive & Positive & 9 \\
\hline Negative & Positive & 12 \\
\hline Positive & Negative & 5 \\
\hline Positive & No & 3 \\
\hline
\end{tabular}

Result: Positive Culture in 21 of 26 (81 per cent.). Positive Slide in 17 of 29 (59 per cent.).

In 484 of the remaining 554 patients whose tests were negative for Trichomonas vaginalis, the organism was sought in the prostatic fluid. This was done by the direct slide method after routine treatment with streptomycin and a sulphonamide drug for non-gonococcal urethritis. Trichomonas vaginalis was found in three of these patients. Thus a diagnosis of trichomonal urethritis was finally made in 32 of 583 patients ( 5.5 per cent.). Fourteen of these 32 patients were whites, and eighteen were Negroes, so that the percentage positive was markedly higher in the latter (Table III).

TABLE III RACE

\begin{tabular}{cc|c|c|c}
\hline \multicolumn{2}{c|}{ Race } & $\begin{array}{c}\text { Total } \\
\text { Cases }\end{array}$ & $\begin{array}{c}\text { T. vaginalis } \\
\text { Positive }\end{array}$ & $\begin{array}{c}\text { Per cent. } \\
\text { Positive }\end{array}$ \\
\hline White $\ldots$ & $\ldots$ & 466 & 14 & 3 \\
Coloured & $\cdots$ & 117 & 18 & 15 \\
\hline Total .. & $\ldots$ & 583 & 32 & $5 \cdot 5$ \\
\hline
\end{tabular}

The ages of the patients with trichomonal urethritis were analysed by decades and also by race; Table IV, (opposite) shows the higher incidence of Trichomonas vaginalis urethritis in the older age groups as compared with gonorrhoea. 
TABLE IV AGE

\begin{tabular}{|c|c|c|c|c|c|c|c|}
\hline \multirow{2}{*}{\multicolumn{2}{|c|}{ Race }} & \multicolumn{3}{|c|}{ White } & \multicolumn{3}{|c|}{ Coloured } \\
\hline & & \multirow{2}{*}{$\begin{array}{r}\text { Total } \\
\text { Cases } \\
232 \\
123 \\
67 \\
27 \\
5\end{array}$} & \multirow{2}{*}{$\begin{array}{c}\begin{array}{c}T . \\
\text { vaginalis } \\
\text { Positive }\end{array} \\
2 \\
5 \\
6 \\
1 \\
0\end{array}$} & \multirow{2}{*}{$\begin{array}{c}\begin{array}{c}\text { Per } \\
\text { cent. } \\
\text { Positive }\end{array} \\
0 \cdot 9 \\
3 \cdot 7 \\
9 \cdot 0 \\
3 \cdot 5 \\
0\end{array}$} & \multirow{2}{*}{ 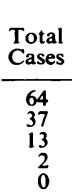 } & \multirow{2}{*}{$\begin{array}{c}\begin{array}{c}T . \\
\text { vaginalis } \\
\text { Positive }\end{array} \\
8 \\
8 \\
2 \\
0 \\
0\end{array}$} & \multirow{2}{*}{$\begin{array}{c}\begin{array}{c}\text { Per } \\
\text { cent. } \\
\text { Positive }\end{array} \\
12 \cdot 5 \\
21 \cdot 6 \\
15 \cdot 4 \\
0 \\
0\end{array}$} \\
\hline $\begin{array}{l}\text { Age } \\
\text { Group } \\
\text { (yrs) }\end{array}$ & $\begin{array}{c}20-29 \\
30-39 \\
40-49 \\
50-59 \\
60+\end{array}$ & & & & & & \\
\hline
\end{tabular}

\section{Contact Tracing}

Eighteen contacts of seventeen patients with trichomonal urethritis were examined in the female clinic. Fifteen of these had trichomonas vaginitis, while in three no trichomonads were found in the vaginal moist slide (although one had clinically suggestive vaginitis and was treated with acetarsol).

\section{Treatment}

To establish that routine chemotherapy and antibiotic treatment of non-gonococcal urethritis is ineffective in trichomonal urethritis, thirty positive patients (two defaulted before treatment) were, where possible, first treated with streptomycin and sulphonamides; when trichomonads recurred, they were re-treated with tetracycline. After a further $T$. vaginalis positive relapse they were finally treated with mercury oxycyanide irrigations and acidification of the urine. An analysis of the surveillance results of these patients is given in Table $\mathrm{V}$.

TABLE V

RESULTS OF TREATMENT IN THIRTY T. VAGINALIS POSITIVE PATIENTS

\begin{tabular}{|c|c|c|c|c|}
\hline \multirow[b]{2}{*}{ Treatment } & \multicolumn{2}{|c|}{ Relapse } & \multirow[b]{2}{*}{ Cure } & \multirow[b]{2}{*}{ Default } \\
\hline & $\begin{array}{c}T \text {. vaginalis } \\
\text { Positive }\end{array}$ & $\begin{array}{c}T \text {. vaginalis } \\
\text { Negative }\end{array}$ & & \\
\hline $\begin{array}{l}\text { Streptomycin and } \\
\text { Sulphonamide } \\
\text { Achromycin } \\
\text { Mercury oxycyanide }\end{array}$ & $\begin{array}{r}17 \\
4 \\
-\end{array}$ & $\overline{2}$ & $\frac{2}{18}$ & $\frac{1}{3}$ \\
\hline
\end{tabular}

During the same period (April, 1956-1957) an analysis was made of the male sex contacts of all female patients with trichomonal vaginitis, who attended the clinic. Of 107 such male contacts who attended the clinic, 56 had non-gonococcal urethritis and in thirteen of them the trichomonad was isolated. Thirty had gonorrhoea, and ten gave a past history of gonorrhoea or non-gonococcal urethritis although no urethritis was present. Only eleven patients were without a history or signs of urethritis (Table VI).

TABLE VI

DIAGNOSIS OF MALE CONTACTS OF $107 T$. VAGINALIS POSITIVE FEMALES

\begin{tabular}{ccccc|c|c}
\hline & & & No. & Per \\
cent.
\end{tabular}

\section{Conclusions}

(1) The number of patients diagnosed in a clinic as having trichomonal urethritis will be increased by using cultural methods.

(2) It is possible to use these methods in the clinic without employing extra clinic or laboratory staff.

(3) The evidence in the literature that trichomonal infection is usually transmitted by sex contact is supported by the fact that, in this series, the majority of male sex contacts of women with trichomonal vaginitis, had or had had some form of urethritis.

(4) The usual routine antibiotic treatment of non-gonococcal urethritis is ineffective in Trichomonas vaginalis urethritis. The only alternative available at present seems to be the use of urethral irrigations.

(5) Infection with $T$. vaginalis appears to be commoner in the age groups, $30-49$ yrs.

Thanks are due to Mr. G. Bird, the supervisor, and to his staff of V.D. technicians, for their cooperation and help.

REFERENCE

Feinberg, J. G., and Whittington, M. J. (1957). J. clin. Path., 10, 327. 